\title{
Typology of housing arrangements of Upper Silesia in 1848-2013 years - archetypes and their modernization flexibility
}

\author{
Jerzy Cibis \\ Faculty of housing and the public utility design, Department of Architecture, \\ Silesian University of Technology, e-mail: jerzy.cibis@polsl.pl
}

\begin{abstract}
In the Polish literature of the subject granted to the residential architecture the most common is the theme of constructed environment, the problem of new trends both in form and design, most often in the context of the sustainable development. More and more frequent are the works on analyzing and describing the sociological perspective of dwelling. Basing on the long-term international and domestic publications and scientific research the spread and often interdisciplinary, complex works and articles concerning the social phenomena in architecture and its surrounding have recently appeared. Despite the huge in amount and the valuable literature as well as the scientific research being led in the last few years the lack of works presenting the complex condition of the residential stock shaped through centuries, in context of usability and needs of the residents, based on the possibilities and real modernisation activities is significant. The time range of the work covers the period from 1848-2013. The broad framework allows the recognition of the vast majority of the existing residential stock and gives the larger spectrum of evaluation in the spotted transformations. Industry initiated the process of the development of the number of contemporary cities.

The work tries to gain the answer for:

- what changes were done to the researched residential stock

- in which period the changes were the most intensive

- in which period the changes were the greatest in the area (both historically and in context of the usability).

Author is also interested in the problem of similarity of the changes to the notes and descriptions of other authors concerning the values of durability and time (so the equipment, the interior divisions, installations, facades and constructions). The present article is used for a projection of these changes on the base of distinctive features of these arrangements and the attempt formulated of characteristic archetype in individual temporary sequences determined in examinations.
\end{abstract}

Keywords: housing arrangements, Upper Silesia, social building development, interwar period, modernism.

\section{Introduction}

The quality which makes modern architecture stand out is the plurality of attitudes, the directions of creative statements. Modern residential architecture should therefore be diversified in these terms. Meanwhile, contemporary typology of functional and spatial layouts of 
multi-family buildings, based in the triad of „klatkowiec - korytarzowiec - galeriowiec” has remained nearly unchanged for decades. The diagnosis by Xavier Gonzales that "architects have abandoned the search for new typological solutions and moved on to elevation modifications and the general appearance of the objects. (...) This phenomenon signifies the end of cohesion, a gradual deepening of the dissonance between theory, typology and morphology in the creative process of an architectural design." remains relevant and valid. The area of Upper Silesia, industrialised at the turn of the 19th and 20th century, where the intense industrial development was accompanied by the building of colonies and workingclass housing, shows an entirely contrary situation. Both historical sources and later conservation studies also indicate major typological variety of this housing complex. And while their architectural form was rather conservative, the housing structure differed very much from the fabric of 19th century cities. When analyzing the method of grouping apartments in buildings and cage segments (klatkowiec) and creating large buildings from repetitive segments, it is difficult not to find correlations with the rules of creating modernist housing estates in the interwar period, applied and developed in multi-family housing throughout many following decades up until today.

\section{Archetypes of housing systems in Upper Silesia}

\subsection{Between 1848 and 1918}

\subsubsection{Tenement house}

The 19th / 20th century tenement house was the basic building element of the city center. Its form, based on the implementation of the building within the boundaries set by narrow plots with access to public space (roads, squares, etc.), has evolved since the Middle Ages. In the ground floor of the tenement, service functions were most often located (in the basement warehouses), higher storeys were reserved for the residential part. The principle of the tenement house was its location in the frontage, i.e. the contact with the walls adjacent to the neighboring properties, which led to the possibility of lighting the flats only from the side of the main facade or the yard. With the development of cities, the standards (mainly surface) of residential premises have changed. The nineteenth century and the aforementioned industrial revolution initiated a rapid influx of people to the cities. Lack of sufficient possibilities for the implementation of new buildings prompted the reconstruction of entire tenement houses and the gradual development of almost the entire plot, leading to so-called Mietskaserne, or „,barracks buildings”, limiting the access of residents to insolation, ventilation of flats, not to mention the greenery. The nineteenth-century tenement houses usually had from three to six storeys, depending on the urbanization degree of the city. External aesthetics of the facade boiled down to the use of elements of broadly defined historicism, in

\footnotetext{
1 klatkowiec - a building in which individual units accessible from staircases are arranged in a sequence, on each floor there are two apartments with windows opening onto both external elevations and possibly further flats, lit only on one side.

korytarzowiec - a multi-family building, where apartments are accessible from a central corridor. Thus, these apartments are lit up unilaterally, have a split levels system or a similar solution.

galeriowiec - apartments are available from the gallery, ie an open communication route, running in front of the façade. There are usually subordinate rooms along the gallery. In the Mediterranean countries, where this type originates, galleries are located from the south, while in countries located further north - along the north elevations. (Source: Wikipedia)
} 
selected cities usually limited to eclecticism or neo-Gothic, or secession. The main entrances to the apartments were from the (mostly) centrally designed main staircase. The flats themselves had a two-bay layout, situating the rooms from the side of the street (or square), and from the courtyard the office, dining room and kitchen. Moreover, the kitchen had a separate entrance from an additional staircase intended for service. In this part of the apartment there was often a small chamber, the so-called "stużbówka", the servant's chamber, with windows overlooking the yard. The standard permitting, small bathrooms were built in the space adjacent to the kitchen and pantry.
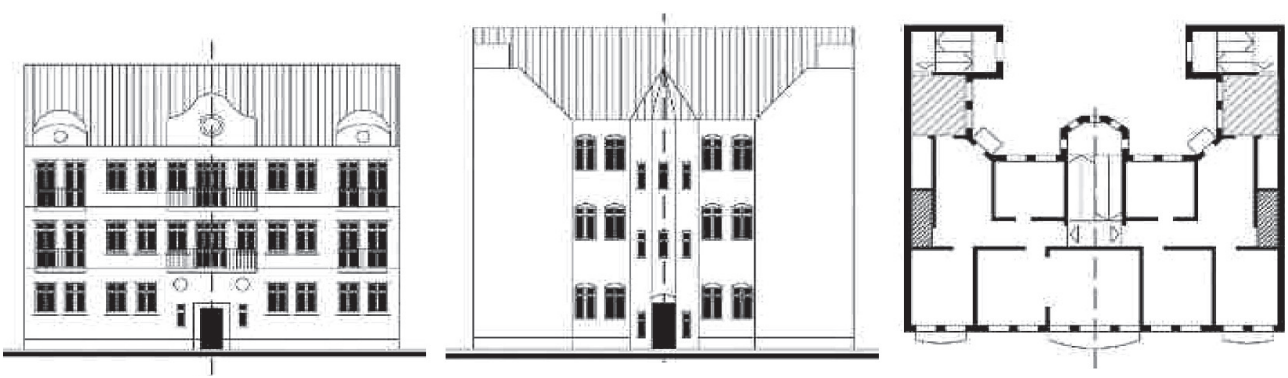

Fig. 1. Typical tenement layout $1848-1918$ (by author)

\subsubsection{Familok}

Familok was the popular name for a building housing several or (more seldom) a dozen flats intended mainly for workers and their families - "familie". It was a form of mass construction, based on architectural solutions unified with different variants. Familoki was the development of the so-called patronage housing estates - housing complexes built by the factory owner on the company premises. The idea of patronage settlements led to a strict translation into architectural solutions. The familok houses were built of brick and had two or three storeys. In the initial period, most of them were deprived of plumbing and toilets, placing those in a commercial building in the yard or, in time, on the landing of a staircase. A typical flat was about 35 square meters and consisted of a kitchen and a room, sometimes a pantry, often referred to as "komórka". Everyday life was concentrated in the kitchen. The room (formerly a chamber) served as a bedroom and a representative room. The flat was inhabited by 6 to 8 people. The distinguishing feature of the Upper Silesian familoki were windows and external window sills, and sometimes also other elements of the external façade, painted by the residents bright red or green.
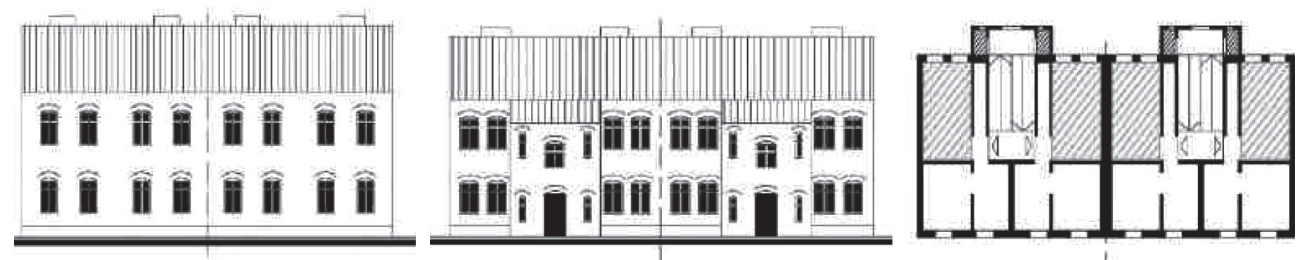

Fig. 2. Typical layout of a familok 1848-1918 (by author) 


\subsection{Between 1919-1945}

\subsubsection{Modernist multi-family housing}

Housing solutions implemented in the midtowns of Upper Silesian cities in the interwar period were an evolutionary step forward in relation to the early tenement house. Erected in place of building gaps, filling in corners or in newly marked quarters, they referred to earlier patterns. However, a strong emphasis was placed on the greater access of light to the rooms, and the strive to unify housing standards determined greater functionality and comfort of use. In addition, in the place of outhouses and scaled backyard buildings, home garden greenery was introduced (often also from the side of the front elevation, in the form of a lawn limited by a hedge). The housing premises were located in a similar way to the nineteenth-century tenement houses, but grouping the kitchens and bathrooms, providing them with insolation and access to fresh air from the yard. An important element of the functional program were also well-lit staircases. In terms of aesthetics, one can distinguish several main stylistic trends of the Upper Silesian architecture of this period: expressionistic, classicizing, functionalist and a stream of simplified forms.
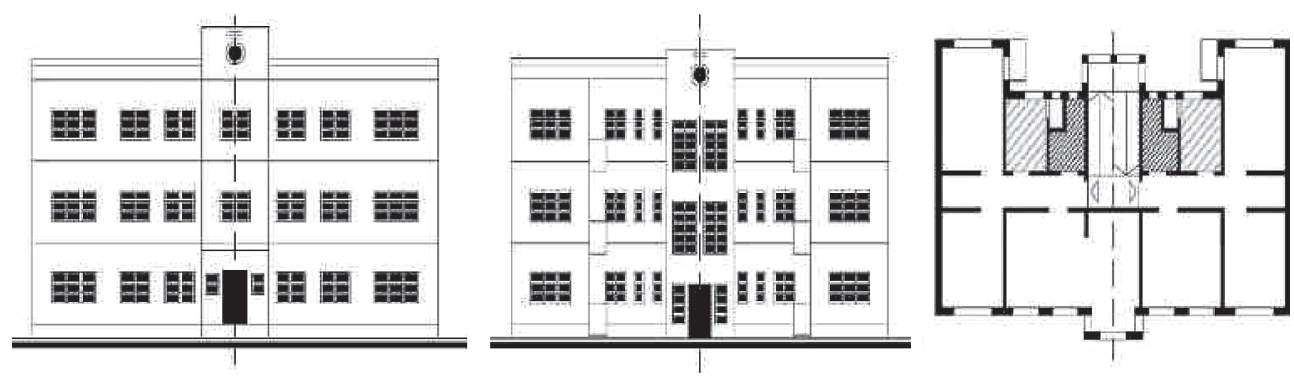

Fig. 3. Typical layout of multi-family housing 1919-45 (by author)

\subsubsection{Modernist single-family housing}

Housing construction solutions, excluding villa buildings, are mostly examples of social housing based on ready-made, repeatable housing cooperative projects.

Due to implementations based on the placement of several segments of single-family housing in the urban context of the layouts of green avenues and squares, such buildings were commonly referred to as "Siedlungi". The most widespread, among others, was a type of a twin building with its ridge facing the street. A one-storey building with an attic containing bedrooms adding more natural light from dormer windows and with outbuildings (with sanitary facilities) joined into a whole range of buildings. Following the example of multi-family buildings in the city center, single-family housing also had small green areas in front of the facade from the street side and a garden behind the house. 

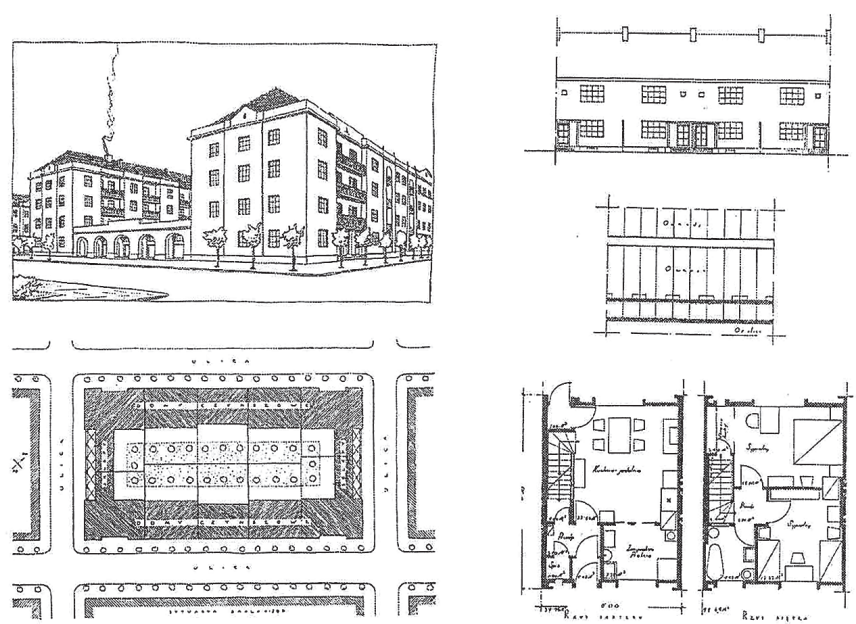

Rys. 162. Projekt domu typowego - W. Blada, Z. Trojanowski, 1926 r. (po lewej) Rys. 163. Projekt domu typowego - N. Weinfeld-Jankowska, 1926 r. (po prawej)

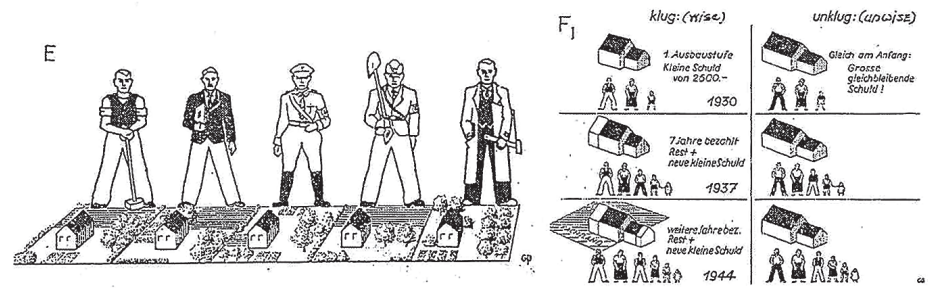

Rys. 164. Idea „mieszkania dla każdego obywatela" - niemiecki material propagandowy, $1935 \mathrm{r}$.

Należy zauważyć, że propagowane przez Republikę Weimarską i III Rzeszę idee i kierunki budownictwa mieszkaniowego w pełni sprostały oczekiwaniom społeczeństwa. Zaspokoiły głód mieszkaniowy lat 20. ubiegłego stulecia oraz jednoczyły w swej formie funkcjonalno-estetycznej interesy państwa i obywatela. Wypracowanie kilku projektów budynków typowych (rys. 165) i czytelne założenia nowej myśli urbanistycznej pozwalały na szybkie i ekonomicznie atrakcyjne realizacje. Tak w przypadku wielorodzinnych budynków mieszkalnych, jak i pośród przykładów zabudowy jednorodzinnej można dostrzec zbieżną estetykę architektoniczną i podobne sposoby rozplanowania pomieszczeń, a jednak dopracowanie detalu i dbałość o zróżnicowanie doprowadziły do wyróżnienia kilkunastu typów budynków tylko na terenie Gliwic.

Fig. 4. The "apartment for each citizen" idea, German propaganda material from 1935
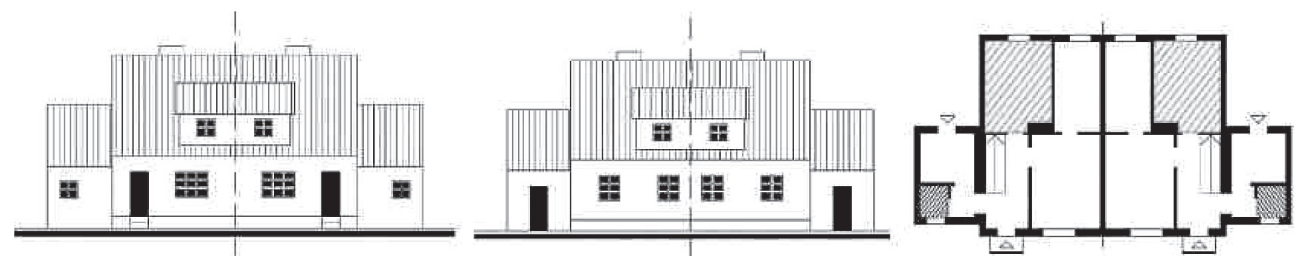

Fig. 5. Typical Siedlung layout 1919-1945 (by author) 


\subsection{Between 1946-1989}

\subsubsection{Large-panel construction}

Large-panel construction technology, i.e. "wielka plyta", is a prestressed structural element, used for modular construction of blocks of flats (as well as other buildings). The form of large-panel buildings was based on façade solutions made of raw concrete without plasters or with prestressed cladding. The structure was based on prestressed concrete elements with reinforcements and fastenings made of steel rods (reinforced concrete), welded plate anchors, and fasteners and hangers were made of stainless steel. The large-panel systems consisted of structured ceiling elements (full or channel) as well as load-bearing, stiffening, partition and elevation walls; as well as ready made staircases and lift and installation shafts, and sometimes full sanitary blocks. The typification was an inseparable element of the whole technology. It included not only the dimensions of components or the solutions of ready-made functional systems, but very often also solutions of the installations applied in the buildings, the method of joining individual panels and sealing of connectors. The projects primarily included functional solutions of entire urban complexes and their units. The main system used in Upper Silesia was Fadom. The solutions included in it included 5-8- and 11 -storey buildings in a transversal arrangement. The prefabricated elements used in this system were manufactured at Fabryki Domów (house factories). The observed tendency of revitalization of large-panel housing estates is a manifestation of striving for sustainable development of the city. However, the most important and the most interesting element of these revitalizations is the occurrence of transformations that can be compared with the changes that accompany architecture in its slow historical development. In this way, a multifaceted, rich architectural legacy with social and cultural elements is created, which is the opposite of the sterile idea of the modernist housing estate.

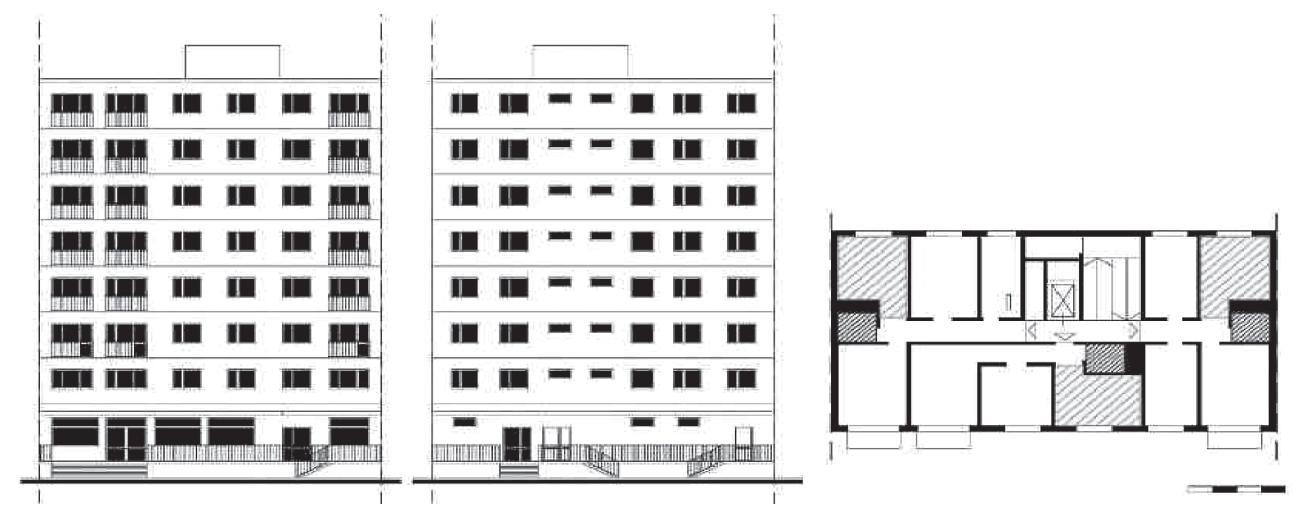

Fig. 6. Typical layout of multi-family housing from the 1990-2013 period (by author)

\subsubsection{Single-family housing - the "Polish cube" (kostka polska)}

The "Polish cube" (kostka polska) refers to the type of a detached building dominant in the landscape at the time - usually two-storey, with a basement, a flat roof or (less often) a hipped "envelope" roof with a very slight decrease. A simple and regular shape, resembling a cube, most often had a repetitive projection on each floor, which often made it a generational 
building (the top was adapted to a separate flat after the staircase was separated). Stairs were added to the building, they were often encapsulated, and the roof of the housing was adapted to be a small terrace. The building material of the "Polish cube" was brick, hollow bricks, etc, available in the era of the PRL (the Polish People's Republic). In several varieties, the "Polish cube" had balconies or trapezoidal extended side walls. There was also a diversified texture of finishing the external walls - from cement and lime plaster, through various types of structural plasters, to crushed plates, mosaics or complete lack of finishing, showing the structure of external wall construction.
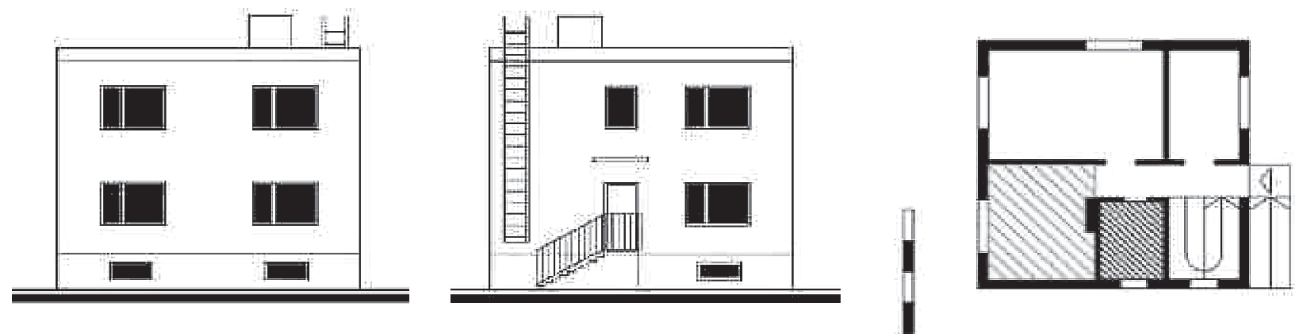

Fig. 7. Typical single-family housing layout in the 1990-2013 period (by author)

\subsection{Between 1990-2014}

\subsubsection{Multi-family housing}

Multi-family housing from the 1990-2013 period amounts to adapting the assumptions of large panel construction to modern standards, set both by users and by building regulations. In relation to previous examples, above all the size of flats was increased, spacious layouts of rooms were introduced whose basic element is a living room with an open kitchenette or kitchen. The gradual departure from large-panel prefabrication limited the schematic and modularity of solutions. The use of diversified contemporary building materials has upgraded the acoustic and thermal insulation standards of apartments, and has paved the way for an unlimited range of interior finishing methods. Apart from special cases, the buildings specified in building regulations as low or mid-high were mostly implemented, initially using the postmodern trend in terms of aesthetics, and then returning to the loosely interpreted modernism. The aesthetics of solutions does not differentiate the manner and principles of the use of residential premises - the construction of the TBS (Towarzystwo Budownictwa Spolecznego, Social Construction Association), cooperative or so-called gated housing (usually apartment buildings) is very similar.
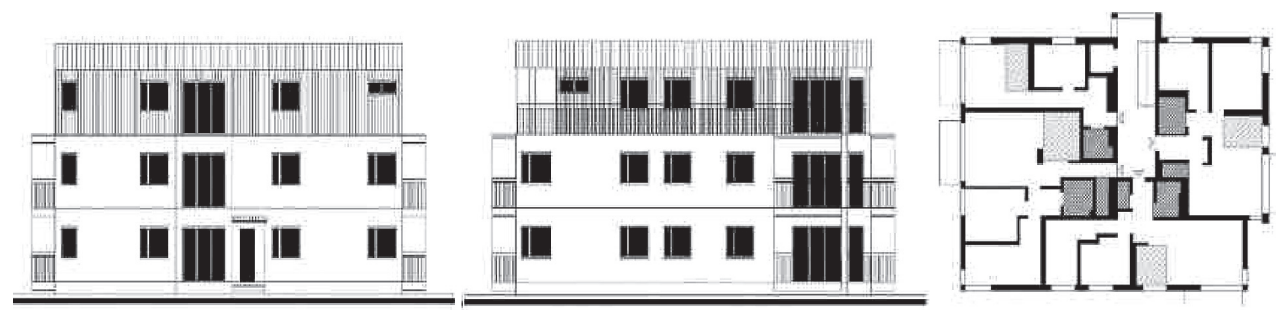

Fig. 8. Typical multi-family housing layout from the 1990-2013 period (by author) 


\subsubsection{Single-family housing}

Single-family housing of the above-mentioned period amounts to very diverse development projects: terraced, semi-detached and detached, reflecting the individual needs of individual users. Thus, the form and aesthetics of solutions span from examples imitating the historical forms of manor houses, by referring to luxury villas of the Corbusier modernism days, to the (most popular) catalog designs of available homes. The dominant element of the interior is a spacious living room combined with an open kitchen, a clearly separated dining room and a large number of home terraces. As in the case of multi-family architecture of this period, the availability of various building and finishing materials gives the possibility of unlimited detailed solutions. The breakthrough in the design of single-family buildings in Europe and Poland took place in the 1990s, although research into passive buildings was conducted in Germany since the 1980s. In 1992-2003, in Western Europe, energy-efficient construction is developing, and passive and ecological houses are gaining popularity, ,supported" by legal regulations and policies of individual countries. The research community has been talking about ,sustainable construction” since as early as 1997. Among the energysaving, low-energy and ecological buildings in recent years, the following types (often interconnected) are distinguished: intelligent, low-emission and passive.
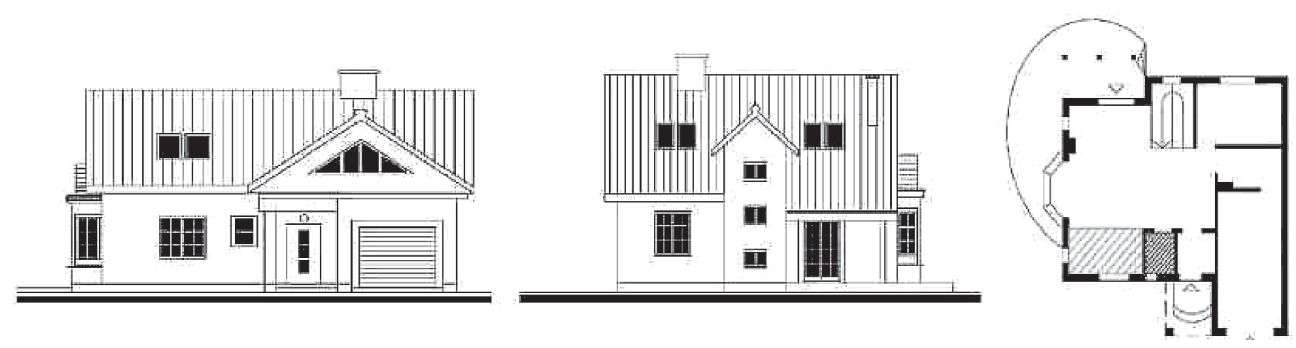

Fig. 9. Typical single-family housing layout from the 1990-2013 period (by author)

\section{Modernization flexibility}

According to Vitruvius, architecture consists in maintaining three principles: durability (Firmitas), usability (Utilitas) and beauty (Venustas). By juxtaposing three groups of modernization changes, they can be assigned to the above. The technical changes are intended to improve and preserve the durability of the living space. Function changes make the existing space more useful to current needs, and changes in aesthetics mainly refer to individual taste and to meet the aesthetic needs of users. Modernization changes are an important indicator allowing to assess the quality and value of the planned residential space in a given time interval. The emerging need for changes by users may on the one hand be perceived as a subjective impulse, caused by real inconvenience or mere current trends; on the other hand however (regardless of the reason), indicates the actual reception of the designed housing space, thus giving a contemporary direction to project activity. Thanks to the analysis of information gathered in this area, for decades to come architects tried to meet the expectations of the statistical majority of users. The presented examples, deeply rooted in the local building and housing tradition, characteristic of the place and time of their formation in the context of diverse political, sociological and historical conditions, give a full picture of the flexibility 
of the archetypes presented, because their technical condition, and above all the design and functional assumptions were subject to only slight transformations, especially in the sphere of technical and aesthetic adaptation to the requirements of the contemporary recipient / user and updating of parametric requirements.

\section{Summary}

The revolution in architecture that took place in the 1920s turned some attention away from the achievements of pre-modern architecture, sometimes appropriating some of them, and the names of modernism precursors erased from the shared memory the names of such outstanding artists as Karl Henrici, Hans von Poelnitz or Arnold Hartmann. Meanwhile, as the example of Upper Silesian workers' settlements seems to indicate, this revolution, at least in relation to the development of multi-family buildings, began much earlier, and Upper Silesia was one of the most important places in which it took place. The multi-family buildings of the historic Upper-Silesian workers' colonies from the turn of the 19th and 20th century are characterized by a different structure than those of the cities of that time, an innovative structure of buildings, created by repetitive, free-standing buildings, often made up of repetitive segments. The design process of historical workers' colonies was characterized by a systemic approach, manifesting itself on the one hand in testing various housing quantities and systems within a selected functional and spatial model, and on the other - in forming typologically diverse buildings based on a unified set of segments. In spite of the conservative, traditional architectural form of buildings, shaping the building structures was also sometimes pioneering, especially where the structure of the building reflected its functional and spatial structure.

\section{References}

[1] Baumschlager C., Eberle D. Über Wohnbau / House-ing. Wien, New York, Springer, 2000. 191 s.

[2] Chojecka E. Sztuka Górnego Śląska od średniowiecza do końca XX wieku. Katowice, Muzeum Śląskie, 2004, $711 \mathrm{s.}$

[3] Cibis J. Identyfikacja zmian architektoniczno-budowlanych zasobów mieszkaniowych z lat 18482013 wybranych miast Górnego Śląska. Gliwice, Wydaw. Politechniki Śląskiej, 2015.

[4] Ebner P., Herrmann E., Hollbacher R., Kuntscher M., Wietzorrek U. Typology+: Innovative Residential Architecture. Basel, Boston, Berlin: Birkhäuser Verlag AD, 2009, 431 s.

[5] Kaczkowski M. Koncepcja renowacji urbanistycznej kolonii Borsig w Zabrzu. Katowice, Biuro Projektów Architektonicznych, 1992.

[6] Ligęza J., Żywirska M. Zarys kultury górniczej. Katowice, Wydawnictwo Śląsk, 1964, 260 s.

[7] Nowogońska B., Cibis J. Technical problems of residential construction. Bristol, Institute of Physics, 2017, art. 052042 s. 1-6. World Multidisciplinary Civil Engineering Architecture-Urban Planning, 2017, DOI:10.1088/1757-899X/245/5/052042

[8] Pfeifer G., Brauneck P. Town Houses: A Housing Typology. Basel; Boston, Berlin, Birkhäuser Verlag AG, 2009, $128 \mathrm{~s}$.

[9] Sattig G. Über die Arbeiterwohnungsverhaltnisse im Oberschlesischen Industriebezirk. Zeitschrift des Oberschlesischen Berg- und Huttenmannischen Vereins, nr 31, 1892.

[10] Seidl K. Das Arbeiterswohnungswessen in der Oberschlesischen Montanindustrie. Selbstverlag des Oberschlesischen Berg- und Hüttenmännischen Vereins, 1913.

[11] Wojtkun G. Wielorodzinne budownictwo mieszkaniowe. W cieniu wielkiej płyty. Przestrzeń i forma, 2010. 